Available Online at: http://ejournal.upbatam.ac.id/index.php/jim

\title{
KEPUASAN MEREK MEMEDIASI PENGARUH SENSORIK MEREK TERHADAP LOYALITAS MEREK TELEPON PINTAR APPLE
}

\author{
Siti Barokah', Oryz Agnu Dian Wulandari², Anisa Nur Andina ${ }^{3}$ \\ Universitas Amikom Purwokerto \\ siti.barokah@amikompurwokerto.ac.id
}

\begin{abstract}
The amount of interest in the use of smartphones has created intense competition among smartphone vendors. Companies are required not only to create customer satisfaction but also to find and build a management system that is professionally able to retain customers. This research is a quantitative study using online survey methods. The samples in this study were all Apple brand smartphone users. the variables used are Brand Sensory, Brand Satisfaction, and Brand Loyalty. Sampling with purposive sampling. Data analysis uses structural equation modeling (SEM) to test models and hypotheses. The analysis shows that brand sensory has a positive effect on brand satisfaction and brand loyalty. Brand Satisfaction has a positive effect on Brand Loyalty. Brand satisfaction mediates the sensory influence of brands on brand loyalty.
\end{abstract}

Keywords: Brand Sensory, Brand Satisfaction, Brand Loyalty

\begin{abstract}
ABSTRAK
Besarnya minat penggunaan telepon pintar menimbulkan persaingan yang ketat antar vendor telepon pintar. Perusahaan dituntut bukan hanya untuk menciptakan kepuasan pelanggan tetapi juga dapat menemukan dan membangun sistem manajemen yang secara profesional mampu mempertahankan pelanggannya. Penelitian ini merupakan penelitian kuantitatif dengan menggunakan metode survey online. Sampel dalam penelitian ini adalah seluruh pengguna telepon pintar merek apple. variabel yang digunakan yaitu Sensorik Merek, Kepuasan Merek, dan Loyalitas Merek. Pengambilan sampel dengan purposive sampling. Analisis data menggunakan structural equation modeling (SEM) untuk menguji model dan hipotesis. Hasil analisis menunjukkan sensorik merek berpengaruh positif pada kepuasan merek dan loyalitas merek. Kepuasan Merek berpengaruh positif pada Loyalitas Merek. Kepuasan merek memediasi pengaruh sensorik merek terhadap loyalitas merek.
\end{abstract}

Kata kunci: Sensorik Merek, Kepuasan Merek, Loyalitas Merek 


\section{Terakreditasi Nasional}

\section{PENDAHULUAN}

Di era globalisasi saat ini tidak dapat dipungkiri bahwa teknologi telah menjadi kebutuhan manusia. Tingginya kebutuhan manusia untuk membantu aktivitas sehari-hari, membuat manusia tidak lepas dari hal-hal yang berkaitan dengan teknologi. Kemajuan teknologi informasi dan telekomunikasi yang semakin maju menawarkan berbagai kemudahan bagi setiap penggunanya. Masyarakat menginginkan suatu alat yang praktis, mudah dipakai, serta multifungsi untuk menjadi bagian dari gaya hidup yang dapat meningkatkan prestige penggunanya. Untuk memenuhi kebutuhan tersebut, maka dibuatlah satu bentuk produk teknologi yang disebut telepon pintar (smartphone).

Pertumbuhan teknologi khususnya telepon pintar saat ini memang sangat pesat baik di dunia maupun di Indonesia. Berdasarkan sekian banyak merek telepon pintar yang telah beredar meramaikan pasar teknologi di Indonesia, Apple merupakan salah satu vendor telepon pintar yang telah beredar meramaikan pasar teknologi di Indonesia. Berikut lima besar vendor telepon pintar dengan penjualan tertinggi sepanjang kuartal kedua tahun 2017 menurut laporan dari firma Gartner. Samsung berada di posisi pertama dengan penjualan 82,5 juta unit telepon pintar. Apple menempati posisi kedua sebanyak 44,3 juta unit telepon pintar yang terjual pada periode April hingga Juni 2017. Posisi ketiga, keempat, dan kelima masingmasing ditempati Huawei 35,9 juta unit telepon pintar, Oppo 26 juta unit telepon pintar, dan Vivo 24 juta unit telepon pintar. Berdasarkan penjelasan tersebut dapat diketahui bahwa apple masih menguasai pangsa pasar telepon pintar di Indonesia dengan menempati posisi kedua di antara vendor telepon pintar yang lain. Hal ini dikarenakan segmentasi apple adalah kalangan menengah ke atas yang menyukai gadget yang menarik secara sensorik (tekno.kompas.com).

Besarnya minat pelanggan terhadap penggunaan telepon pintar tentu menimbulkan persaingan yang ketat antar vendor telepon pintar. Ketatnya persaingan membuat perusahaan dituntut bukan hanya untuk menciptakan kepuasan pelanggan namun juga untuk dapat menemukan dan membangun sistem manajemen yang secara profesional mampu mempertahankan pelanggannya.
Faktor-faktor yang dapat membangun loyalitas pelanggan terhadap merek diantaranya yaitu pengalaman merek, kepribadian merek, kepuasan dan kepercayaan (Kim et. al., 2015; Cleff et. al., 2013; Sahin et. al., 2011; Brakus et. al., 2009).

Penelitian ini mengacu pada penelitian yang telah dilakukan oleh Kim et. al., (2015) yang meneliti tentang kepuasan dan loyalitas dari pengalaman merek yang memuat dimensi sensorik, afektif, perilaku, intelektual dan kepribadian merek yang memuat dimensi ketulusan, kemampuan, kegembiraan, kecanggihan, dan kekasaran. Berbeda dengan penelitian yang telah dilakukan oleh Kim et. al., (2015), penelitian ini hanya berfokus pada dimensi sensorik merek karena konsumen akan lebih mudah untuk mengevaluasi pengalaman terhadap faktor estetika dan persepsi melalui kelima inderanya yaitu penglihatan, pendengaran, penciuman, perasaan, dan perabaan.

\section{TINJAUAN PUSTAKA Loyalitas Merek}

Loyalitas merek merupakan preferensi konsumen secara konsisten untuk melakukan pembelian pada merek yang sama pada produk yang spesifik atau kategori pelayanan tertentu (Schiffman dan Kanuk, 2004). Loyalitas merek merupakan suatu ukuran keterkaitan pelanggan kepada sebuah merek. Ukuran ini mampu memberikan gambaran tentang mungkin atau tidaknya seorang pelanggan beralih ke merek lain yang ditawarkan oleh competitor, terutama jika pada merek tersebut didapati adanya perubahan, baik menyangkut harga maupun atribut lainnya (Aaker, 1997). Dick dan Basu (1994) mengkonseptualisasikan loyalitas pelanggan sebagai gabungan dari sikap dan perilaku. Mereka menunjukkan bahwa kesetiaan adalah hasil interaksi antara sikap relatif pelanggan terhadap merek atau penyimpanan dan perilaku pembelian berulang terhadap merek atau toko tersebut. Pelanggan dengan loyalitas sikap dan perilaku tinggi digambarkan sebagai "loyalitas sejati", pelanggan dengan loyalitas perilaku tinggi namun loyalitas sikap rendah digambarkan sebagai "loyaltas palsu", pelanggan yang memiliki loyalitas sikap tinggi namun loyalitas perilaku rendah digambarkan sebagai "loyalitas laten", dan pelanggan yang meiliki loyalitas sikap dan perilaku rendah 


\section{Available Online at: http://ejournal.upbatam.ac.id/index.php/jim}

digambarkan sebagai "tidak setia". Loyalitas merek tidak terbentuk dalam waktu yang singkat, tetapi melalui prose belajar atau proses pencarian informasi dan berdasarkan pengalaman konsumen dari pembelian yang konsisten sepanjang waktu.

Ada beberapa faktor yang dapat menyebabkan pelanggan loyal terhadap suatu merek. menurut Brakus et. al., (2009) loyalitas merek dapat terbentuk melalui pengalaman merek, kepribadian merek, dan kepuasan merek. Sahin et. al., (2011) juga menyebutkan bahwa loyalitas merek dapat terbentuk melalui pengalaman merek, kepuasan merek, dan kepercayaan merek. Berdasarkan uraian tersebut maka dapat disimpulkan bahwa loyalitas merek dapat terbentuk melalui pengalaman merek, kepribadian merek, kepuasan dan kepercayaan merek.

\section{Sensorik Merek}

Pengalaman merek didefinisikan sebagai pengalaman yang dirasakan atau dialami pelanggan yang berasal dari kumpulan interaksi antara pelanggan dengan produk, perusahaan, atau bagian dari organisasi tersebut yang menimbulkan reaksi (Gentile et. al., 2007). Konsumen tidak memiliki pengalaman dengan merek tertentu ketika mereka tidak terbuka pada beberapa stimuli yang terkait dengan merek tersebut, misalnya warna, bentuk, jenis huruf yang digunakan, slogan atau mascot maupun ketika mereka sedang membeli maupun mengkonsumsinya (Meyers-Levy dan Peracchio, 1995; Veryzer dan Hutchinson, 1998; Mandel dan Johnson, 2002; Keller, 1987). Pengalaman terhadap merek terjadi ketika pelanggan mencari informasi tentang produk, membeli produk tersebut, merasakan layanan, dan menggunakan maupun mengkonsumsi produk tersebut (Choi et. al., 2011). Berdasarkan uraian tersebut dapat disimpulkan bahwa pengalaman merek merupakan pengalaman yang dirasakan oleh pelanggan yang terjadi ketika pelanggan mencari informasi tentang produk, menggunakan maupun mengkonsumsi produk atau layanan pada suatau merek tertentu.

Pengalaman merek dapat memberikan pengaruh positif pada kepercayaan merek. Pengalaman merek juga memiliki peran penting dalam menumbuhkan loyalitas, kepuasan pelanggan, menciptakan word-ofmouth yang positif, kredibilitas merek, dan sikap yang baik terhadap merek (Khan dan Fatma, 2017). Pengalaman merek juga dapat menumbuhkan kepuasan pelanggan, meningkatkan loyalitas merek dan kepribadian merek (Kim et. al., 2015). Menurut Keng et. al., (2013) mengungkapkan bahwa pengalaman merek dapat mempengaruhi nilai pengalaman pelanggan dan kepribadian merek. Berdasarkan uraian tersenbut dapat disimpulkan bahwa pengalaman merek dapat memberikan pengaruh pada kepercayaan merek, loyalitas merek, kepuasan pelanggan, kepribadian merek, word-of-mouth, kredibilitas merek, sikap terhadap merek, dan nilai pengalaman pelanggan. Brakus et. al., (2009) mengemukakan bahwa pengalaman merek terdiri dari empat dimensi yaitu sensorik, afektif, perilaku, dan intelektual.

\section{Kepuasan Merek}

Secara umum, kepuasan adalah perasaan senang atau kecewa seseorang yang muncul setelah membandingkan kinerja (hasil) produk yang dipikirkan terhadap kinerja (atau hasil) yang diharapkan. Jika, kinerja berada di bawah harapan, pelanggan tidak puas. Jika kinerja memenuhi harapan, pelanggan puas. Jika kinerja melebihi harapan, pelanggan amat puas atau senang (Kotler dan Keller, 2009). Oliver (1997) menjelaskan bahwa kepuasan adalah tingkat perasaan seseorang setelah membandingkan hasil yang dirasakan dengan harapannya. Sedangkan menurut Zeithaml dan Bitner (2000) kepuasan didefinisikan sebagai respon atau tanggapan konsumen mengenai pemenuhan kebutuhan. Berdasarkan penjelasan tersebut dapat disimpulkan bahwa kepuasan konsumen yaitu suatu tanggapan perilaku konsumen berupa evaluasi pasca beli terhadap suatu barang atau jasa yang dirasakannya dibandingkan dengan harapan konsumen.

Kepuasan tidak terjadi begitu saja, melainkan dibentuk melalui faktor-faktor tertentu. Kapferer (2008) berpendapat bahwa faktor penentu utama kepuasan pelanggan adalah gap antara pengalaman pelanggan dengan harapan pelanggan dan pemosisian mereklah yang membentuk harapan pelanggan. Westbrook dan Reilly dalam Tjiptono (2008) juga menjelaskan bahwa kepuasan pelanggan sebagai respon emosional terhadap pengalaman-pengalaman yang berkaitan dengan produk atau jasa tertentu yang dibeli, gerai ritel, atau bahkan pola 


\section{Terakreditasi Nasional}

\section{Available Online at: http://ejournal.upbatam.ac.id/index.php/jim}

perilaku (seperti prilaku berbelanja dan perilaku pembeli), serta pasar secara keseluruhan. Menurut Brakus et. al., (2009) kepuasan pelanggan dapat dibentuk oleh faktor pengalamn merek dan kepribadian merek. Berdasarkan uraian tersebut dapat disimpulkan bahwa kepuasan pelanggan dapat terbentuk melalui pengalaman merek dan kepribadian merek. Kepuasan pelanggan juga dapat menyebabkan pelanggan tetap loyal pada merek tertentu karena pelanggan yang puas cenderung akan tetap bertahan pada merek tersebut dan tidak akan mudah untuk berpindah pada merek pesaing (Sahin et. al., 2011). Pelanggan yang puas juga akan mempengaruhi citra perusahaan karena ketika pelanggan itu puas mereka akan terkesan dengan citra perusahaan karena ketika pelanggan itu puas mereka akan terkesan dengan citra perusahaan tersebut (Jani dan Han, 2014). Berdasarkan uraian tersebut dapat disimpulkan bahwa kepuasan pelanggan dapat menyebabkan pelanggan loyal terhadap suatu merek tertentu dan dapat memberikan pengaruh baik pada citra perusahaan.

\section{METODOLOGI PENELITIAN}

Penelitian ini merupakan penelitian kuantitatif dengan menggunakan metode survey online. Sampel dalam penelitian ini adalah seluruh pengguna telepon pintar merek apple. Variabel yang digunakan dalam penelitian ini yaitu sensorik merek, kepuasan merek, dan loyalitas merek. Hair et. al., (1996) dalam Suliyanto (2011) mengemukakan bahwa ukuran sampel yang sesuai untuk SEM adalah 100-200. Sampel minimum adalah lima observasi untuk setiap estimated parameter. Penelitian ini menggunakan indikator dengan 23 parameter, maka ukuran sampel minimum yang akan diambil adalah 23 x $5=115$ sampel.

Teknik pengambilan sampel dalam penelitian ini adalah purposive sampling dengan kriteria sebagai berikut:

1) Pria/wanita usia $\geq 18$ tahun karena responden sudah dewasa dan rasional dalam bersikap.

2) Pernah membeli telepon pintar merek apple $\geq 1$ kali agar responden dapat menggambarkan sensorik merek, kepuasan merek, dan loyalitas merek.

3) Pernah menggunakan telepon pintar merek apple $\geq 1$ tahun agar responden dapat menggambarkan sensorik merek, kepuasan merek, dan loyalitas merek.

Pengambilan data dilakukan dengan membagikan kuesioner secara online melalui media sosial facebook, instagram, dan whatsapp. Setelah dilakukan penyebaran kuesioner diperoleh sebanyak 188 kuesioner yang kembali. Namun, dalam penelitian ini yang akan digunakan hanya 147 kuesioner yang memenuhi kriteria penelitian. Penyusunan instrument dalam penelitian ini didasarkan pada instrument yang telah dikembangkan oleh peneliti-peneliti sebelumnya yang sebagian besar diadopsi dari jurnal internasional. Skala pengukuran variabel dalam penelitian ini adalah skala likert tujuh poin. Analisis data menggunakan structural equation modeling (SEM) untuk menguji model dan hipotesis. Model dalam penelitian ini disajikan dalam gambar 1 berikut:

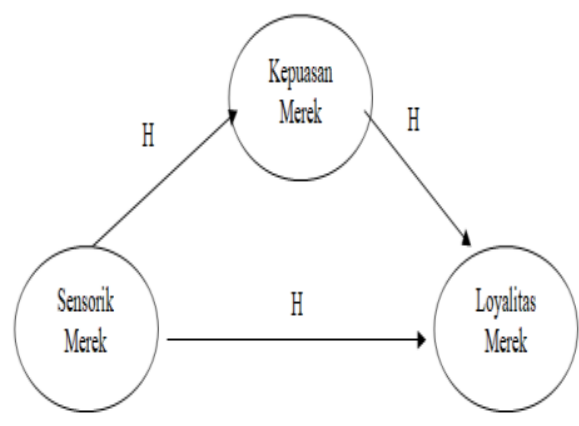

Gambar 1. Model Penelitian

Hipotesis dalam penelitian ini berdasarkan model penelitian tersebut adalah sebagai berikut:

H1 : Sensorik merek berpengaruh positif pada kepuasan merek.

H2 : Kepuasan merek berpengaruh positif pada loyalitas merek.

H3 : Sensorik merek berpengaruh positif pada loyalitas merek.

H4 : Kepuasan merek memediasi hubungan pengaruh sensorik merek pada loyalitas merek.

\section{HASIL DAN PEMBAHASAN}

Responden pada penelitian ini dibatasi pada pelanggan telepon pintar merek apple yang berusia $\geq 18$ tahun yang pernah melakukan pembelian telepon pintar merek apple minimal satu kali dan lama penggunaan 


\section{Terakreditasi Nasional}

\section{Available Online at: http://ejournal.upbatam.ac.id/index.php/jim}

minimal satu tahun. Pelaksanaan pengumpulan data dilaksanakan pada Bulan Juli 2018 dengan menyebar kuesioner secara online.

a. Uji validitas dan reliabilitas

Uji validitas dalam penelitian ini digunakan untuk mengetahui valid atau tidaknya suatu alat ukur yang digunakan dalam melakukan fungsi ukurannya. Sedangkan uji reliabilitas dalam penelitian ini digunakan untuk menunjukkan tingkat konsistensi dan stabilitas alat ukur atau instrument penelitian dalam mengukur suatu konsep atau konstruk. Berikut ini adalah hasil perhitungn dari uji validitas dan uji reliabilitas:

Tabel 1. Hasil pengujian validitas dan

\begin{tabular}{|c|c|c|c|c|}
\multicolumn{5}{c|}{ reliabilitas } \\
\hline \multirow{2}{*}{ Construct } & \multirow{2}{*}{ Item } & \multicolumn{3}{|c|}{ Convergent Validity } \\
\cline { 3 - 5 } & & $\begin{array}{c}\text { Loading } \\
\text { Factor }\end{array}$ & $\begin{array}{c}\text { Construct } \\
\text { Reliability }\end{array}$ & $\begin{array}{c}\text { Variance } \\
\text { Extracted }\end{array}$ \\
\hline Sensorik & x1 & 0,814 & & \\
Merek & x2 & 0,707 & & \\
& x3 & 0,703 & 0,895 & 0,587 \\
& x4 & 0,777 & & \\
& x5 & 0,812 & & \\
& x6 & 0,775 & & 0,652 \\
Kepuasan & x7 & 0,754 & & \\
Merek & x8 & 0,845 & 0,903 & \\
& x9 & 0,783 & & \\
& x10 & 0,847 & & \\
& x11 & 0,805 & & \\
\hline Loyalitas & x12 & 0,613 & & \\
Merek & x13 & 0,885 & \multirow{2}{*}{0,885} & \\
& x14 & 0,863 & & \\
& x15 & 0,862 & & \\
&
\end{tabular}

Sumber: Data diolah.

Berdasarkan hasil output standardized loading tersebut, secara umum nilai loading factor signifikan secara statistik dan sudah lebih dari 0,5, sehingga dapat disimpulkan bahwa indikator masing-masing variabel valid. Variance extracted dihitung sebagai total kuadrat standardized factor loading (squared multiple correlation) dibagi dengan total kuadrat standardizes loading ditambah total varians dari error. Nilai AVE sama dengan atau di atas 0,50 menunjukkan convergent yang baik. Berdasarkan hasil uji perhitungan variance extract, dapat disimpulkan bahwa nilai AVE masing-masing variabel memiliki nilai lebih dari 0,5 sehingga data dalam penelitian ini layak untuk digunakan. Selain itu, pada tabel 1 diperoleh nilai construct reliability lebih dari cut-off $(0,70)$ sehingga dapat disimpulkan bahwa semua variabel dalam penelitian ini adalah konsisten atau reliabel.

b. Uji Kelayakan Moodel

Setelah dilakukan uji validitas dan reliabilitas, selanjutnya dilakukan pengujian model dengan melihat nilai goodness-of-fit index. Uji data kesesuaian model dapat dilihat pada gambar 1 dan tabel 2 berikut.:

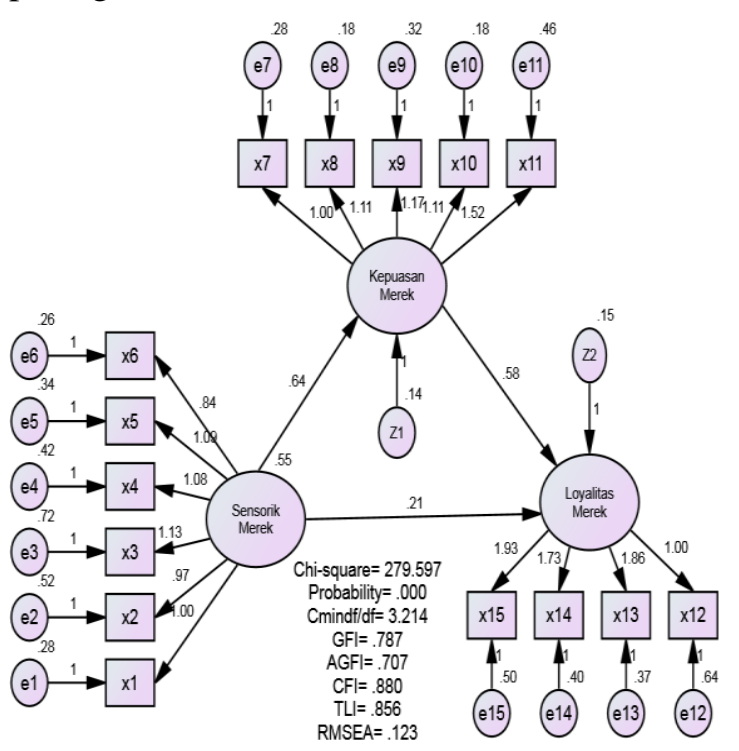

Gambar 1.

Model Persamaan Struktural Standardized

Tabel 2. Uji Kelayakan Model

\begin{tabular}{|c|c|c|c|}
\hline $\begin{array}{c}\text { Goodness } \\
\text { of Fit Index }\end{array}$ & $\begin{array}{c}\text { Cut Off } \\
\text { Value }\end{array}$ & $\begin{array}{c}\text { Hasil } \\
\text { Analisi } \\
\mathrm{s}\end{array}$ & $\begin{array}{c}\text { Evaluasi } \\
\text { Model }\end{array}$ \\
\hline Chi-Square & $\begin{array}{c}\text { Diharapka } \\
\text { n kecil }\end{array}$ & $\begin{array}{c}279,59 \\
7\end{array}$ & \\
\hline $\begin{array}{l}\text { Significanc } \\
\mathrm{e} \\
\text { probability }\end{array}$ & $\geq 0,05$ & 0,000 & $\begin{array}{c}\text { Margina } \\
1\end{array}$ \\
\hline RMSEA & $\leq 0,08$ & 0,123 & $\begin{array}{c}\text { Margina } \\
1\end{array}$ \\
\hline GFI & $\geq 0,90$ & 0,787 & Margina \\
\hline AGFI & $\geq 0,90$ & 0,707 & $\begin{array}{c}\text { Margina } \\
1\end{array}$ \\
\hline CMIN/DF & $\leq 2,00$ & 3,214 & $\begin{array}{c}\text { Margina } \\
1\end{array}$ \\
\hline TLI & $\geq 0,95$ & 0,856 & Margina \\
\hline $\mathrm{CFI}$ & $\geq 0,95$ & 0,880 & Margina \\
\hline
\end{tabular}

Sumber: Data diolah 


\section{Terakreditasi Nasional}

\section{Available Online at: http://ejournal.upbatam.ac.id/index.php/jim}

Hasil analisis yang ditampilkan pada tabel 2 menunjukkan bahwa model diterima walaupun secara marginal. Model tersebut tidak termasuk a very good fit, tetapi model ini termasuk a better fit.

c.uji hipotesis

Pengujian hipotesis dilakukan dengan analisis structural equation model, hasil analisis structural equation model sensorik merek, kepuasan merek terhadap loyalitas merek telepon pintar apple akan disajikan dalam tabel 2 berikut:

Tabel 3. Uji Hipotesis

\begin{tabular}{|l|l|l|r|r|r|r|}
\hline & & & Estimate & S.E. & C.R. & P \\
\hline Kepuasan_Merek & $<---$ & Sensorik_Merek & .642 & .079 & 8.092 & $* * *$ \\
\hline Loyalitas_Merek & $<---$ & Kepuasan_Merek & .582 & .147 & 3.955 & $* * *$ \\
\hline Loyalitas_Merek & $<---$ & Sensorik_Merek & .214 & .104 & 2.063 & .039 \\
\hline \hline
\end{tabular}

Sumber: Data diolah

\section{H1 : Sensorik merek berpengaruh positif pada kepuasan merek}

Berdasarkan tabel 2 dapat diketahui bahwa pengaruh sensorik merek pada kepuasan merek memiliki nilai critical ratio (C.R.) sebesar 8,092 >1,96 dengan signifikansi sebesar $0,000<0,05$. Berdasarkan hasil pengujian tersebut dapat diartikan bahwa sensorik merek memiliki pengaruh positif pada kepuasan merek. Sehingga hipotesis pertama yang menyatakan sensorik merek berpengaruh positif pada kepuasan merek telepon pintar apple diterima. Hal tersebut menandakan bahwa semakin banyak stimulus pada pengalaman sensorik merek yang sesuai dengan yang diharapkan oleh konsumen maka semakin tinggi tingkat kepuasan pelanggan pada telepon pintar merek apple. Karena telepon pintar merek apple mampu memberikan kesan yang kuat kepada konsumennya baik secara visual, pendenganran, perasaan maupun perabaan. Sehingga, konsumen telepon pintar merek apple merasa puas dan senang dengan keputusannya untuk membeli telepon pintar merek apple dan benar-benar menikmati saat menggunakan telepon pintar merek apple serta merasa menjadi pengalaman yang baik ketika menggunakan telepon pintar merek apple. Hasil penelitian ini sesuai dengan hasil penelitian yang dilakukan oleh Sahin et. al., 2011; Chinomona, 2011; Cleff et. al., 2013; dan Kim et. al., 2015 yang menemukan bahwa pengalaman merek yang memuat dimensi sensorik, afektif, perilaku dan intelektual memiliki pengaruh positif pada kepuasan merek.

\section{H2 : Kepuasan merek berpengaruh positif pada loyalitas merek}

Berdasarkan tabel 2 dapat diketahui bahwa pengaruh kepuasan merek pada loyalitas merek memiliki nilai critical ratio (C.R.) sebesar 3,955 > 1,96 dengan signifikansi sebesar $0,000<0,05$. Berdasarkan hasil pengujian tersebut dapat diartikan bahwa kepuasan merek memiliki pengaruh positif pada loyalitas merek. sehingga hipotesis kedua yang menyatakan bahwa kepuasan merek berpengaruh positif pada loyalitas merek telepon pintar merek apple diterima. Hal ini menandakan bahwa konsumen merasa kebutuhannya terpenuhi oleh telepon pintar merek apple sehingga mereka merasakan kepuasan merek dan akan meneruskan penggunaan maupun pembeliannya serta bersedia untuk menjadi pelanggan setia pada telepon pintar merek apple. Konsumen puas dengan telepon pintar merek apple karena telepon pintar merek apple memberikan pengalaman yang baik bagi konsumen sehingga konsumen benar-benar menikmati ketika menggunakan telepon pintar merek apple dan yakin bahwa menjadi pelanggan telepon pintar merek apple adalah hal yang benar. Hasil penelitian ini sesuai dengan penelitian yang dilakukan oleh Sahin et. al. (2011) yang menemukan bahwa kepuasan merek memiliki pengaruh positif pada loyalitas merek. Hasil penelitian ini juga 


\section{Terakreditasi Nasional}

\section{Available Online at: http://ejournal.upbatam.ac.id/index.php/jim}

didukung dengan hasil penelitian yang dilakukan oleh Jani dan Han (2014) dan Kim et. al. (2015) yang menemukan bahwa kepuasan merek berpengaruh positif pada loyalitas merek. Loyalitas merek terjadi karena kinerja dari merek tersebut dapat memenuhi segala harapan konsumen pada merek.

\section{H3 : Sensorik merek berpengaruh positif pada loyalitas merek}

Berdasarkan tabel 2 dapat diketahui bahwa pengaruh sensorik merek pada loyalitas merek memiliki niali critical ratio (C.R.) sebesar 2,063> 1,96 dengan signifikansi sebesar 0,39. Berdasarkan hasil pengujian tersebut dapat diartikan bahwa sensorik merek berpengaruh positif pada loyalitas merek. Sehingga hipotesis ketiga yang menyatakan bahwa sensorik merek berpengaruh positif pada loyalitas merek telepon pintar merek apple diterima. Hal ini menandakan bahwa telepon pintar merek apple menarik secara sensorik. Telepon pintar merek apple dapat memberikan kesan hi-tech yang kuat pada penggunanya dan mampu memberikan ketertarika secara keseluruhan karena telepon pintar merek apple mampu mempertahankan ciri khasnya seperti memiliki desain yang sederhana namun tetap elegan sehingga telepon pintar merek apple dianggap sebagai telepon pintar yang eksklusif dan membuat penggunanya merasa lebih percaya diri ketika menggunakannya. Hasil penelitian ini didukung oleh hasil penelitian yang telah dilakukan oleh Sahin et. al., 2011; Jani dan Han, 2014; dan Kim et. al., 2015 yang menemukan bahwa sensorik merek memiliki pengaruh positif pada loyalitas merek.

H4 : Kepuasan merek memediasi sensorik merek dengan loyalitas merek.

Berdasarkan hasil analisis sobel test, dapat diketahui bahwa nilai $\mathrm{z}$ menunjukkan nilai sebesar 3,559 > 1,96 dengan signifikansi 0,000 $<0,05$. Hal ini membuktikan bahwa kepuasan merek memediasi hubungan pengaruh sensorik merek terhadap loyalitas merek. Sensorik merek merek memiliki pengaruh positif yang signifikan terhadap loyalitas merek melalui kepuasan merek. Loyalitas merek cenderung akan meningkat karena kepuasan merek semakin baik dan meningkat yang disebabkan oleh semakin baiknya sensorik merek. Hasil penelitian ini didukung oleh hasil penelitian Sahin et. al., (2011) yang mengemukakan bahwa kepuasan merek memediasi hubungan pengalaman merek terhadap loyalitas merek.

\section{KESIMPULAN}

Berdasarkan analisa data penelitian, maka dapat disimpulkan bahwa sensorik merek memiliki pengaruh positif pada kepuasan merek dan loyalitas merek. Hal ini menandakan bahwa semakin banyak stimulus pada pengalaman sensorik merek yang sesuai dengan yang diharapkan oleh konsumen maka semakin tinggi tingkat kepuasan konsumen pada telepon pintar merek apple. Selanjutnya, dari analisa data penelitian juga dapat disimpulkan bahwa kepuasan merek berpengaruh positif pada loyalitas merek. Hal ini menandakan bahwa semakin tinggi tingkat kepuasan konsumen pada telepon pintar merek apple, maka akan semakin tinggi loyalitas konsumen pada telepon pintar merek apple.

Selain itu, pada penelitian ini juga dapat dibuktikan bahwa sensorik merek berpengaruh positif pada loyalitas merek. Hal ini menandakan bahwa semakin banyak pengalaman sensorik merek yang dilalui oleh pengguna telepon pintar merek apple maka akan semakin tinggi loyalitas pelanggan pada telepon pintar merek apple. Karena, konsumen telepon pintar merek apple merasa lebih mudah merasakan ketertarikan secara keseluruhan pengalaman sensoriknya melalui alat indera. Dalam penelitian ini juga dapat dibuktikan bahwa kepuasan merek memediasi hubungan pengaruh sensorik merek pada loyalitas merek. Semakin baik dan meningkat kepuasan merek yang disebabkan dari pengalaman sensorik merek maka akan cenderung meningkatkan loyalitas merek merek.

\section{SARAN}

Berdasarkan penelitian yang telah dilakukan maka terdapat saran yang dapat diberikan yaitu model dalam penelitian ini memenuhi kriteria goodness-of-fit secara marginal atau belum memenuhi kriteria a very good fit. Sehingga penelitian selanjutnya disarankan untuk menambahkan jumlah sampel penelitian dan menambahkan variabel lain yang dapat meningkatkan loyalitas merek. 


\section{Terakreditasi Nasional}

Available Online at: http://ejournal.upbatam.ac.id/index.php/jim

DAFTAR PUSTAKA

Aaker, A. David. 1997. Manajemen Ekuitas Merek. Jakarta: Mitra Utama.

Brakus, J.J., Schmitt, B.H \& Zarantonello, L. (2009). "Brand Experience : What is it? How is it Meassured? Does it Affect Loyalty?. Journal of Marketing. Vol.73, No.2, pp.

Chinomona, Richard. 2013. The Influence Of Brand Experience On Brand Satisfaction, Trust And Attachment In South Africa. International Business \& Economics Research Journal.

Choi, Y. G., Ok, C., dan Hyun, S. S. 2011. Evaluating Relationship among Brand Experience, Brand Personality, Brand Prestige, Brand Relationship Quality, and Brand Loyalty: An Empirical Study of Coffeehouse Brands.

Cleff et. al. 2013. Brand Experience-How It Relates to Brand Personality, Consumer Satisfaction And Consumer Loyalty. An Empirical Analysis Of The Adidas Brand. Interdisciplinary Management Research.

Dick, Alan S. dan Kunal Basu. 1994. Customer Loyalty: Toward an Integrated Conceptual Framework. Journal of the Academy of Marketing Science. Volume 22, No. 2, pages 99113.

Gentile, C., Spiller, N., dan Noci, G. 2007. How to sustain the customer experience: an overview of experience components that co-create value with the cusomer. European Management Joural. 25 (5), 395-401.

Jani, Dev dan Heesup Han. 2014. 'Personality, satisfaction, image, ambience, and loyalty: Testing their relationships in the hotel industry'. International Journal of Hospitality Management. 37, 11-20.

Kapferer, J-N. 2008. The new strategic brand management, creating and sustaining brand equity long term. London: Kogan.

Keller, K. L. 1987. Memory Factors in Advertising: The Effects of Advertising Retrieval Cues on Brand Evaluations. Journal of Consumer Research. 14 (December): 316-33.

Keng, Ching-Jui, Van-Dat Tran, dan Tuyet Mai le Thi. 2013. Relationships among Brand Experience, Brand Personality, And Customer Experiential Value.
Contemporary Management Research. Pages 247-262, Vol. 9, No. 3.

Khan, Imran dan Mobin Fatma. 2017. Antecedents and outcomes of brand experience: an empirical Study. Journal Brand Management.

Kim, Ji Wan, Freddy Lee dan Yong Gu Suh. 2015. Satisfaction and Loyalty From Shopping Mall Experience and Brand Personality. Services Marketing Quarterly. 36:62-76.

Kotler, Philip dan Kevin Lane Keller. 2009. Manajemen Pemasaran. Jilid I: Edisi ke13. Jakarta: Erlangga.

Mandel, N., dan Johnson, E. J. 2002. When Web pages influence choice: Effects of visual primes on experts and novices. Journal of Consumer Research. 29(2), 235-245.

Meyers-Levy, J. dan L.A. Peracchio. 1995. How the Use of Color in Advertising Affects Attitudes: The Influence of Processing Motivation and Cognitive Demands. Journal of Consumer Research. 22 (September): 121-38.

Oliver, Richard L.1997. Satisfaction: A behavioral perspective on the consumer. Boston, MA: McGraw-Hill.

Sahin, Azize, Cemal, Zehir, dan Hakan, Kitapci. 2011. The Effects of Brand Experiences, Trust and Satisfaction on Building Brand Loyalty; An Empirical Research On Global Brands. Procedia Social and Behavioral Sciences.

Schiffman, Leon G. dan Leslie Lazar Kanuk. 2004. Perilaku konsumen. Edisi ketujuh. Jakarta: PT. Indeks Gramedia.

Suliyanto. 2011. Ekonometrika Terapan. Edisi: 1. Yogyakarta: Andi Offset.

Tjiptono, Fandy. 2008. Pemasaran Jasa. Malang: Bayu Media Publishing.

Veryzer, R.W. dan J.W. Hutchinson. 1998. The Influence of Unity and Prototypicality on Aesthetic Responses to New Product Designs. Journal of Consumer Research. 24 (March): 37494.

Zeithaml, V.A. dan Bitner, M.J. 2000. Service marketing: Integrating customer focus across the firm. Second edition. New York: Irwin McGraw-Hill Publishing Company. 